\title{
DEVELOPING ESP MATERIALS FOR TOURISM INDUSTRY IN MALANG
}

\author{
Masyhud $^{1}$, Khoiriyah ${ }^{2}$ \\ 1,2 University of Muhammadiyah Malang \\ ${ }^{1}$ masyhud863@umm.ac.id, ${ }^{2}$ khoiriyah230693@umm.ac.id
}

\begin{abstract}
This article explores the need for English as a mean of communication for the tourism industry in Malang. Since the need for English speaking skills is immensely demanded, this community service program was proposed to provide a ready-use module to facilitate the locals practising their English speaking skills. Hence, this study reported on-going project designing English for Specific Purposes (ESP) materials for the tourism industry in Malang. It is implemented in three stages: planning stage, implementation stage and evaluation. Specifically, the target learners are Karang Taruna members who are working in tourism near Kelurahan Jodipan. Since there are many thematic villages there, the learning content is designed contextually with the local wisdom and local culture. Hence, it is projected to help the locals provide better services for their visitors, especially foreign visitors.
\end{abstract}

Keywords: ESP, Materials Design, English for Tourism

\section{INTRODUCTION}

Some new tourism objects in a lagging rural region are fascinating as it will bring some benefits for the local communities. There are three fundamental benefits of tourism for residents: sustainable income, improved local services, cultural empowerment, and cultural exchange. Many tourists, especially foreigner, enjoy meeting and interacting with the local people and learning the traditional cultures. In this term, the local community should consider their services and hospitality to the visitors. To provide the traditional cultural nuance, community involvement, mostly residents, is highly important to design some tourism programs such as guided tour, traditional art performance, and others.

The newly introduced thematic tourism object "Kampung Biru Arema" has been announced by the Government of Malang City. This tourism object is one of the government's attempts to transform the riverbank area (DAS) into a more prosperous area where the locals can develop their economic, social, and cultural potentials through its tourism activities. This new tourism village was established in 2017. The head of Planning, Research and Development Agency of Malang City (Kepala Badan Perencanaan, Penelitian, dan Pengembangan Pemkot Malang), Erik Setyo Santoso explained that there are more than 500 houses in riverbank area which were coloured blue. These houses are located in the Kidul dalem sub-district, next to Jodipan (KWJ) Colorful kampong, 3D kampong (tridi), Kampung Lampion, and White kampong. Those tourism destinations are located in Kelurahan Jodipan, Malang City.

In Malang, the Head of Education and Tourism Board stated that until August 2019, the number of foreign visitors in Malang are increasing double from last year 15 million in total (as cited by jatim.antaranews.com, 2019). The main tourism destinations are wisata sejarah bangunan kuno peninggalan Belanda, Kampung Warna Warni Jodipan, Kampung 3D, Kampung Eco Green Purwantoro, dan Kampung Putih. There are 11 thematic villages for local tourism. Many 
foreigners enthusiastically visit Kampung Biru Arema because they are curious about the history and the local community of AREMA. They also eager taking pictures at Kampung Tridi, and Kampung Lampion. However, rarely, are the locals able to speak English with foreigners. As a result, disrespectful interest is shown by the visitors. As Fujita et al. (2017) and Prachanant (2012) reported, one of the obstacles to being a thriving local destination for the growth of tourism industry is the lack of foreign language skills, especially English.

Table 1. The Number of Foreigners and Domestic Visitors to East Java (2019)

\begin{tabular}{lrr}
\hline Period & Foreigners & Domestic visitors \\
\hline October & 29671 & 1039326 \\
\hline November & 24977 & 1118776 \\
\hline December & 22653 & 1359475 \\
\hline Total & $\mathbf{3 6 6 ~ 8 3 5}$ & $\mathbf{1 3 8 4 3 4 0 3}$ \\
\hline Source: BPS East Java & &
\end{tabular}

To become a more globalized tourism destination, the local community needs to consider the importance of language mastery (such as English) to communicate with foreigners. Based on the preliminary need analysis conducted in November 2019, most of the stakeholders in Kelurahan Jodipan agreed that the most significant obstacle that the local community faced is communication with the foreigners. Thus, this community service aims to empower the locals, especially Karang Taruna, to communicate using English with foreigners. Moreover, there are several Rukun Warga in Keluharahan Jodipan. This community service will focus on RW 3 as these will be promoted as Kampung Batik. There are many Karang Taruna members (around 27 members) who are still studying in secondary school. Their educational background is possible to train them as a professional tour guide. Hence, developing an English training program will enable the locals to be a professional tour guide for local and foreign visitors.

To solve these issues, intensive English-language courses would be a prospective solution. However, coursebooks tailored to the needs of a particular student group are unlikely to be available. As an initial effort, designing contextualized materials is deemed to be done. To create a contextualized teaching materials, needs analysis has been one of the primary pre requested aspects. This material development is mostly related theories regarding English for Specific Purposes (ESP) as the materials are developed based on the learners' needs. Those theories are associated with this study's context since Robinson in Nurpahmi (2016) defined two ESP course criteria: ESP usually is 'goal-directed', and ESP courses develop from a needs analysis. It means that a needs analysis aims to define precisely what the students have to learn through English. ESP is usually restricted by a limited amount of time in which the learning objectives have to be accomplished. It is taught in homogenous classes in terms of the job or specific context in which the students are involved.

The model for designing ESP materials consists of four essential elements: input, content, language and task (Hutchinson \& Waters, 1987). First, input refers to language learning sources such as text, dialogue, video-recording and many more. The language input should include several things: 1) stimulus materials for activities; 2) new language items; 3) correct models of language use; 4) a topic for the communicative task, and 5) opportunities for learners to use their information processing skills and their prior knowledge both of the language and the content. Second, content focus demands that language conveys information or delivers feeling and non-linguistic content to create more meaningful information. Meanwhile, language focus facilitates students to learn the language into pieces, study how it works and practice it. It 
enables learners to use the language and have enough language knowledge. Lastly, related to the task, the ultimate objective of language learning is language use. By integrating content and language knowledge, materials should be designed for a communicative task. The materials should be developed related to those four elements. The language and content are taken from the input, while the task is selected according to what the learners would need to do. Therefore, ESP material development aims to allow learners to perform adequately in a target situation based on their need.

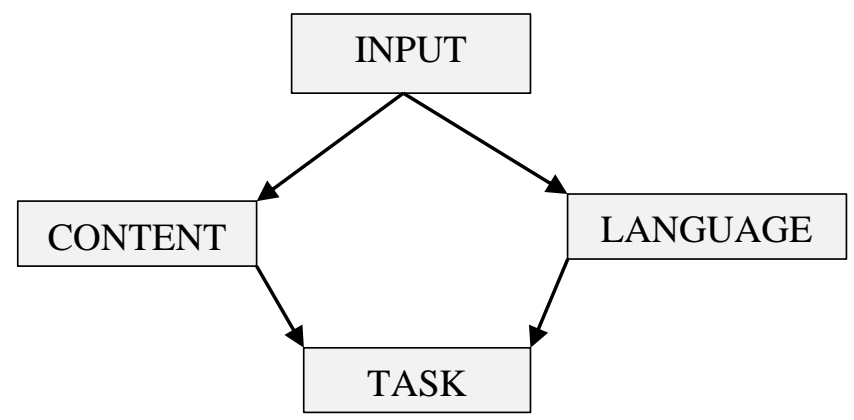

Figure 1. A model of ESP material development by Hutchinson and Waters (1987)

Some previous studies have been done related to material development for the tourism industry in Indonesian context in a nutshell. Ratminingsih et al., (2018) presented the result of need analysis for designing a contextualized-based language teaching for local tour guides in Bali. In the same line, Widiyati (2015) also investigated the need for prospective tour guides of Desa Menari in Semarang regency to experience better English. Additionally, Gani and Damayanti (2018) conducted a quantitative and qualitative descriptive research to determine the local tour guides' speaking ability at the Aceh Tsunami Museum. Referring to those previous studies, a practical guide to developing ESP materials for tourism industry, especially in Malang regency remains limited. As a result, this paper provides some insight and guideline for designing ESP materials for tourism.

\section{METHOD}

This community service is carried out to solve the target community's issues by giving adequate English training in their environment. After conducting the discussion with several locals at Kelurahan Jodipan, it will focus on "English for Tourism" material development to prepare English training for Karang Taruna (the Youth Organization) to be a professional tour guide. Further, this community service is aimed to produce ESP materials for the tourism industry. In detail, the program will be implemented in three stages: planning, implementation and evaluation.

Concerning the planning stage, it will be conducted by having a thorough need analysis done through an interview with the stakeholders of Kelurahan Jodipan. The stakeholders will identify issues in English as their conversation and analyze the possible solutions for the problems. Besides, observation will also be carried out to provide an accurate and comprehensive situational analysis, so that the community service program can target the issues adequately. In implementing stage, community service program is carried out in the form of ESP material development. In detail, English material will be in English for Specific Purposes, particularly English for Tourism as the target is in the tourism industry. Lastly, the evaluation is essential 
to identify the impact, strength, and weakness of material development. It will be achieved by having a comprehensive discussion with the related stakeholder and experts.

\section{RESULTS AND DISCUSSION}

\section{Results}

The present community was projected to solve the main problems faced by Kelurahan Jodipan, which are related to tourism promotion and tourism hospitality, especially for foreign visitors. Moreover, providing a module and a video tour guide simulation is the suspicious answer for the problems. To provide contextualized learning materials, the project team formulated the fundamental steps as it is shown as follows:

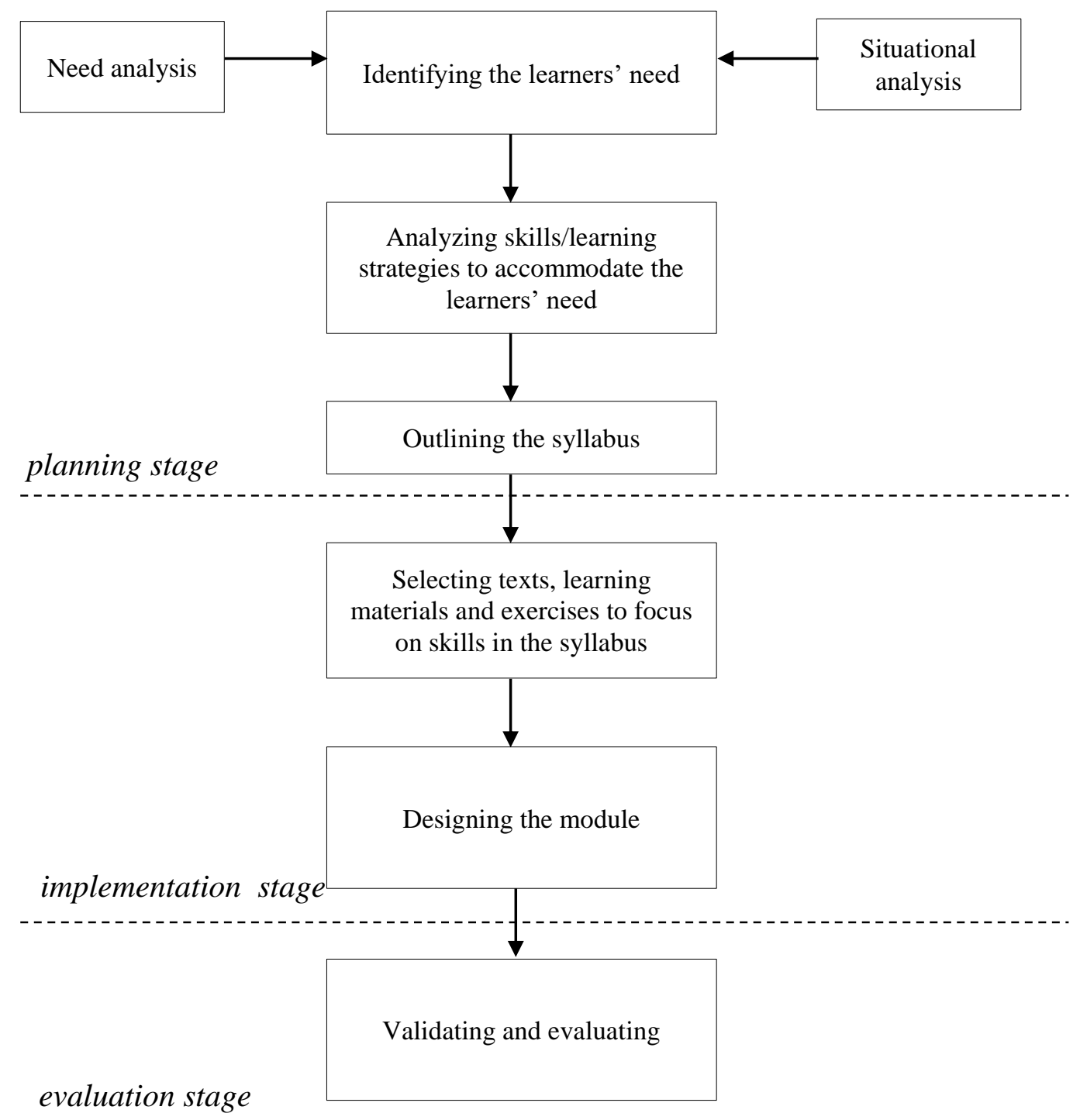

Figure 2. Steps in designing English for tourism materials

The figure above shows that designing the course materials starts with conducting need analysis and situational analysis. This step aims to identify the learners' need and formulate the projected learning materials. Based on those result, the project team analyzed the skills needed by the learners. The skills should be integrated among four required skills including listening, 
speaking, reading and writing. Yet, based on the preliminary need analysis, the most crucial skills is speaking. After that, the syllabus is designed as well as the module. Lastly, the readyuse module is evaluated and validated by the expert. This course design implemented a learnercentred course design. Hence, it is in line with Nurpahmi's work (2016) stating that learnercentred course design is the best solution for providing specific English registers as a framework for ESP and to the practical constraints on learning imposed by limited time and resources. The goal is ultimately to make the learners into better specific skill by their needs. The details are explained as follows.

\section{Planning stage}

In the planning stage, the project team conducted need analysis and situational analysis to the target learners. In this context, the target learners are the local, including Karang Taruna (ranging from 15 years old up to 25 years old). They are working to provide services for visitors in Jodipan tourism objects. This step is essential in determining appropriate materials for stakeholders. This community service conducted need analysis by interviewing the head of RW (Rukun Warga), chief of Karangtaruna, and PKK. The interview has been applied for several times to acquire the basic need for English tourism. After conducting the need analysis, the team planned possible solutions to overcome the encountered problems. The data from the interview and the possible solutions were summarized as follows:

Table 2. The summary of the community service process

\begin{tabular}{|c|c|c|c|}
\hline Problems & Solution & Method & Target \\
\hline $\begin{array}{l}\text { 1. Program partner has } \\
\text { limited facilities in } \\
\text { learning English. }\end{array}$ & $\begin{array}{l}\text { Providing additional } \\
\text { facilities for teaching } \\
\text { materials }\end{array}$ & $\begin{array}{lr}\text { Providing } & \text { English } \\
\text { materials } & \text { for } \\
\text { English } & \text { tourism } \\
\text { context } & \\
\end{array}$ & $\begin{array}{l}\text { Involvement } \\
\text { Karangtaruna }\end{array}$ \\
\hline $\begin{array}{l}\text { 2. Program partner } \\
\text { needs English } \\
\text { materials. }\end{array}$ & $\begin{array}{ll}\text { Providing } & \text { teachers } \\
\text { development }\end{array}$ & $\begin{array}{l}\text { Assisting useful } \\
\text { materials for } \\
\text { program partner }\end{array}$ & $\begin{array}{l}\text { Useful materials will } \\
\text { lead to effective } \\
\text { teaching. Effective } \\
\text { teaching will lead to } \\
\text { the Eglish } \\
\text { improvement }\end{array}$ \\
\hline $\begin{array}{l}\text { 3. Program partner } \\
\text { needs English } \\
\text { handbook for } \\
\text { tourism. }\end{array}$ & $\begin{array}{l}\text { Providing materials } \\
\text { which focus on English } \\
\text { for tourism }\end{array}$ & $\begin{array}{l}\text { Developing a } \\
\text { handbook }\end{array}$ & $\begin{array}{l}\text { Comprehensive } \\
\text { understanding to } \\
\text { develop ESP } \\
\text { materials }\end{array}$ \\
\hline
\end{tabular}

Based on the above table, several needs were identified. First, local people have limited English mastery. Otherwise, they should accompany foreigners to move around Jodipan. They felt confused to communicate. As a result, they tend to keep silent without any information to give to visitors. Sometimes, they felt guilty because they just accompanied them to walk without any information they could get. It was noticed that local people try to promote local tourist destinations internationally, but they have minimal English skills (Fujita et al., 2017). Therefore, they need an English course. Second, they need a handbook which can be easily brought. They can use the book as guidance for them if they should communicate with foreigners. The last is they need an example to do a tour guide. The result of need analysis remains crucial since the need analysis's objectives are twofold: to define the subjects, language functions and abilities, and local culture content of the materials necessary for the course and to design the teaching materials for the course (Sari, 2016). 
To be specific, the project team prioritized to provide a ready-use module for having intensive English training. Hence, this community service is supported by experts who have been experienced in teaching and designing English materials, especially in ESP context. Further, to develop the syllabus, determining the materials' topics is the next stage conducted by this community service. In determining the material, focused group discussion (FGD) were involved, two lecturers and four students. Finally, the project team decided the topics based on the result of need analysis. There are eight topics, as presented in the following table.

Table 3. Selected topics for designing English for tourism module

\begin{tabular}{|c|c|c|c|}
\hline No. & Topics & $\begin{array}{l}\text { Language point (including the } \\
\text { vocabulary in the context) }\end{array}$ & Skill objective \\
\hline 1 & $\begin{array}{l}\text { Introduction and } \\
\text { welcoming } \\
\text { tourist }\end{array}$ & $\begin{array}{l}\text { Self-introduction, greeting, } \\
\text { welcoming expression }\end{array}$ & $\begin{array}{l}\text { Speaking: To introduce } \\
\text { ourselves, do the greeting, do } \\
\text { welcoming expression }\end{array}$ \\
\hline 2 & $\begin{array}{l}\text { Giving and } \\
\text { Asking } \\
\text { Information }\end{array}$ & Giving and Asking expression & $\begin{array}{l}\text { Speaking: To express Giving } \\
\text { and Asking for information. }\end{array}$ \\
\hline 3 & $\begin{array}{l}\text { Giving } \\
\text { Directions }\end{array}$ & Giving Directions & $\begin{array}{l}\text { Speaking: To express Giving } \\
\text { Directions }\end{array}$ \\
\hline 4 & $\begin{array}{l}\text { Describing } \\
\text { People and Place }\end{array}$ & Describing People and Place & $\begin{array}{l}\text { Speaking: To express } \\
\text { Describing People and Place }\end{array}$ \\
\hline 5 & $\begin{array}{l}\text { Offering and } \\
\text { requesting }\end{array}$ & Offering and requesting & $\begin{array}{l}\text { Speaking: To express } \\
\text { Offering and requesting }\end{array}$ \\
\hline 6 & $\begin{array}{l}\text { Handling } \\
\text { Complaint }\end{array}$ & Handling Complaint & $\begin{array}{l}\text { Speaking: To express } \\
\text { Handling Complaint }\end{array}$ \\
\hline 7 & $\begin{array}{l}\text { Explaining } \\
\text { Safety, Rule, } \\
\text { Etiquette and } \\
\text { customs }\end{array}$ & $\begin{array}{l}\text { Explaining Safety, Rule, } \\
\text { Etiquette and customs }\end{array}$ & $\begin{array}{l}\text { Speaking: To express } \\
\text { Explaining Safety, Rule, } \\
\text { Etiquette and customs }\end{array}$ \\
\hline 8 & Making report & Making report & $\begin{array}{l}\text { Speaking: To express } \\
\text { Making report }\end{array}$ \\
\hline
\end{tabular}

Furthermore, the community service formulated the template of the module. The template was merely focused on speaking skill. Speaking skills are considered the most crucial skill compared to other skills that are crucially needed in the tourism industry. This statement is supported by (Gani \& Damayanti, 2018; Nurhamidah et al., 2020; Ratminingsih et al., 2018; Widiyati, 2017) stating that mostly the target learners in tourism industry need to improve their speaking skills.

\section{Implemention stage}

The next step is selecting the learning source such as text, dialogue, and materials and designing the module based on the selected topics. In developing the module, the learning activities were focused more on practice than language form, which would trigger the learners to have many speaking exercises. The template consists of each unit's topic, objectives, brief introduction, warming-up activities or brainstorming, vocabulary list, some useful expressions, grammar focus, the example of conversation, and task / role-play. 


\section{Conversation 4}

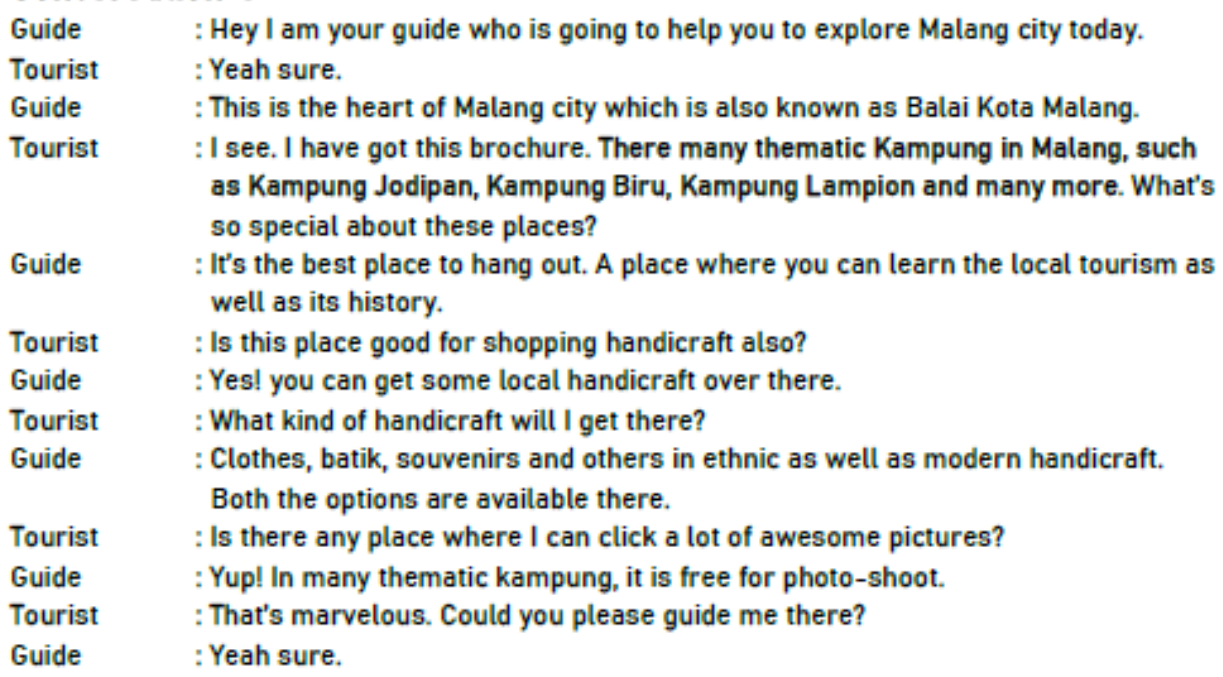

\section{Let's speak}

Practice the dialog with your partner to ask and give detailed information above. Any of the details, such as time, entertainment name, restaurant, food served, etc., must be changed.
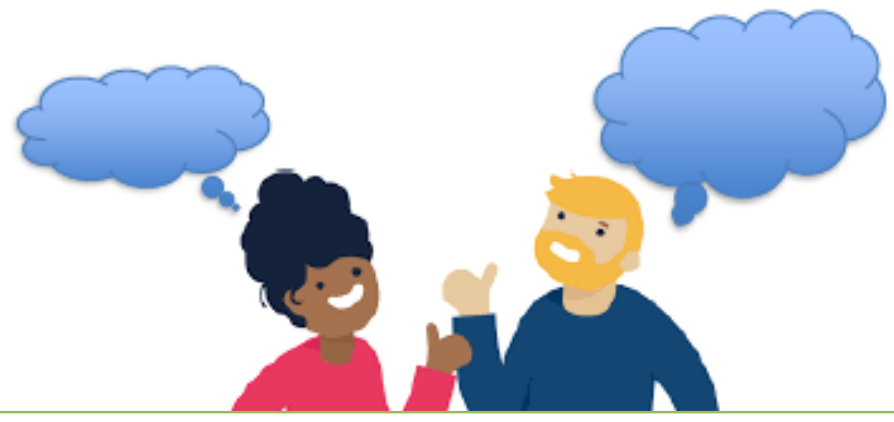

Figure 3: An example of speaking activity

Further, since the language learning is specified in a particular context, the tasks in which as instructional activity has some criteria to be fulfilled such as 1) the main focus of the task is on meaning, not grammatical learning 2) the result of language use should be related to the real world, especially for tourism in Jodipan thematic village, and 3) communicative goal is clearly stated as the outcome of the learning activities. As a result, tasks focus on encouraging the target learners to comprehend the contextualized content to have a specific learning experience. 


\section{Activity 5 - Let's read (Information about tourism object)}

Read the following passage and identify some information about a tourist attraction.

\section{Selecting} contextualized text (based on the situation in Jodipan)

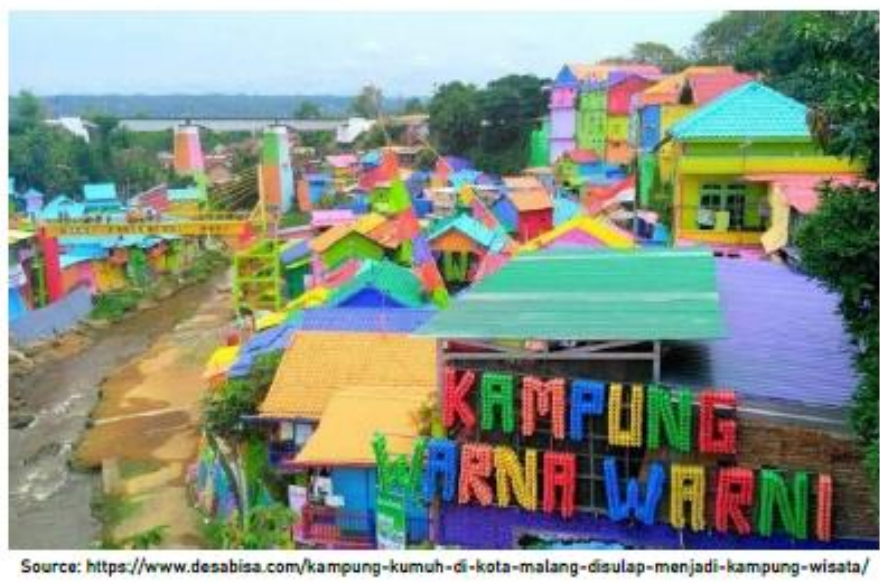

\section{Kampung Warna-Warni, Jodipan}

Malang is one of the highland towns in East Java, about $90 \mathrm{~km}$ from Surabaya City. Malang has cool weather and is very good for holidays due to its location in the highlands. Malang is certainly the place worth exploring, Malang has it all, with the stunning mountain ranges to the delicious foods that the city can provide. One of the most popular destinations is Kampung Jodipan. The town on the banks of the Berantas River has now been turned into a location that is often packed with photographers and tourists. The Embong Berantas Bridge connecting Jodipan Village with Tridi Village is an interesting place in Jodipan Village. Thanks to the slum management council that has transformed the village into a beautiful, clean and definitely

Figure 4: An example of contextualized materials

Based on the selected topics, language skills and local culture aspects were also considered to be inserted in designed materials or learning activities. As Petvoca in Sari (2016) stated that "local culture can be included to enrich the new linguistic experience, encourage (motivate) learners by providing them with something familiar to them, and train them to talk about their own culture to other foreign-language speakers". More importantly, the understanding between foreign and local cultures should be mastered by the target learners. Since they will interact with the foreigners, they also should get familiar with their custom and culture. Take an example, in greeting; Western culture is relatively different from Asian culture. Hence, the module also provides some cross-cultural understanding materials. The sample can be seen as follows: 


\section{Activity 1 - Greetings}

There are many ways of greeting people, even before you say a word. How you do this will rely on a lot of factors, such as your nationality and culture, how well you know the person you meet, your relative ages, and your gender. Before doing so, you ought to think about who you meet and greet.

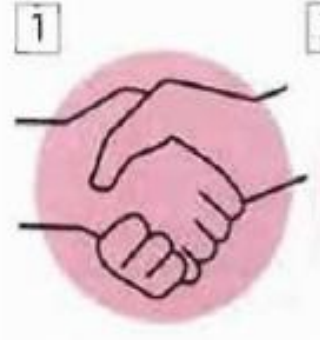

4

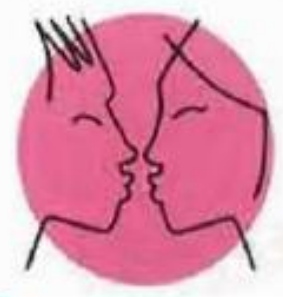

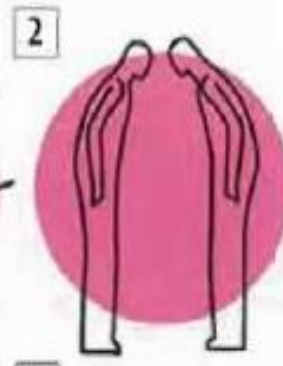

5

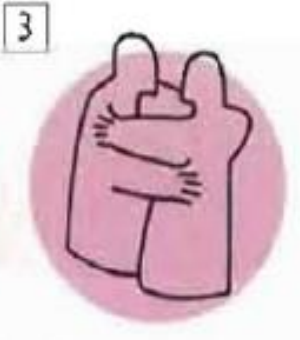

6
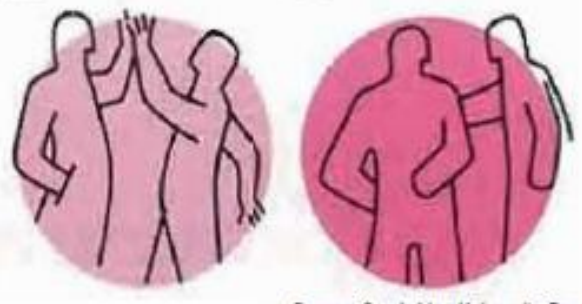

Source: Cambridge University Pres

Would you use these greetings? In which situations?

Figure 5: An example of speaking activity related to cross-culture understanding

\section{Evaluating stage}

ESP experts and a curriculum specialist have tested the design process for these ESP materials to satisfy the criteria for the results' validity and reliability. There are two English lecturers involved in this program with various expertise. One lecturer concerns teaching English for specific purposes such as tourism, hospitality, etc. Another lecturer focuses on designing materials and teaching intensive English. Furthermore, they have been teaching English for more than eight years to have plenty of teaching and developing English materials. Evaluating and validating the topics must be considered to get valid issues that are fit for English Tourism. It is necessary to review an ESP module to know whether the skills are covered, the kinds of activities offered are suitable, and the appropriate topics are given (Purwanti, 2019). Therefore, the community service team discussed with other English lecturers and tourism practitioners. The details are as follows:

Table 3: The detailed Information about the validators

\begin{tabular}{cllll}
\hline No. & Identity & $\begin{array}{l}\text { Teaching } \\
\text { Experience }\end{array}$ & Expertise & Departments \\
\hline 1. & Validator 1 & 12 years & $\begin{array}{l}\text { Curriculum and materials } \\
\text { development }\end{array}$ & $\begin{array}{l}\text { English Language Education } \\
\text { Department of UMM }\end{array}$ \\
\hline 2. & Validator 2 & 6 years & $\begin{array}{l}\text { Designing English } \\
\text { materials and media }\end{array}$ & $\begin{array}{l}\text { English Language Education } \\
\text { Department of UMM }\end{array}$ \\
\hline 3. & Validator 3 & - & $\begin{array}{l}\text { Working in hospitalized } \\
\text { sectors }\end{array}$ & Tourism practitioner \\
\hline
\end{tabular}




\section{CONCLUSION}

In short, this community service program attempts to help the Jodipan's Karang Taruna problem with English communication. It is formulated by providing a module that can be a handbook for them to talk with foreigners. When designing instructional materials for particular ESP learner programs, such as English for tourism, analyzing the need for ESP is a must. In selecting the content materials, contextualized materials, and the learning context's local culture should be integrated as they reflect the target learners' real-world interactions and promote language learning. In addition, the current community service also provided some exemplary videos to do a tour guide. This can be a model for the target learners to practice doing a tour guide as part of tourism hospitality.

On the other hand, the present community service encountered some practical problems, mostly when Covid 19 outbreak spread massively. This module should be tailored to the target learners, yet the project team decided to postpone it. Therefore, it is essential to conduct the piloting project for the follow-up program. Further, in conducting need analysis, this study mainly used interviews, questionnaires, field observation and other instruments are suggested for further research to have more comprehensive results.

\section{ACKNOWLEDGMENTS}

This ESP material development is a part of community service being projected for stakeholders of tourism industries in Malang. It was supported by Directorate of Research and Community Service (DPPM) University of Muhammadiyah Malang.

\section{REFERENCES}

Fujita, R., Terui, M., Araki, T., \& Naito, H. (2017). An analysis of the English communication needs of people involved in tourism at Japanese rural destinations. Journal of Global Tourism Research, 2(1), 53-58. https://doi.org/10.37020/jgtr.2.1_53

Gani, S. A., \& Damayanti, C. I. (2018). The ability to speak English of the local tour guides for promoting tourism at the Aceh Tsunami Museum. Studies in English Language and Education, 5(2), 269-278. https://doi.org/10.24815/siele.v5i2.11178

Hutchinson, T., \& Waters, A. (1987). English for specific purposes: A learning-centred approach. Cambridge University Press.

Nurhamidah, I., Hartono, \& Purwanto, S. (2020). Pengadaan brosur dwibahasa bagi obyek wisata Desa Menari, Ngrawan, Getasan Kabupaten Semarang. Indonesian Journal of Community Services, 2(1), 27-37.

Nurpahmi, S. (2016). ESP Course Design: an Integrated Approach. Lentera Pendidikan : Jurnal Ilmu Tarbiyah Dan Keguruan, 19(2), 172-181. https://doi.org/10.24252/lp.2016v19n2a4

Prachanant, N. (2012). Needs analysis on English language use in tourism industry. Procedia Social and Behavioral Sciences, 66, 117-125. https://doi.org/10.1016/j.sbspro.2012.11.253

Purwanti, A. R. (2019). Evaluation on an ESP Course Book: Get Along with English for the Hotel Industry. JEES (Journal of English Educators Society), 4(2), 107. https://doi.org/10.21070/jees.v4i2.2432

Ratminingsih, N. M., Suardana, M., \& Martin, A. A. N. Y. (2018). English for tour guide: A need analysis of a contextual-based language teaching. SHS Web of Conferences, 42, 1-6. https://doi.org/10.1051/shsconf/20184200012

Sari, R. A. (2016). Teaching English for tourism in Bali based on local culture: What do students need? Proceedings of the Fourth International Seminar on English Language 
and Teaching (ISELT-4), 221-229.

Widiyati, E. (2017). Analyzing the need of prospective tour guides in acquiring English to communicate with foreign tourist in Desa Menari as tourim village. The 1st Education and Language International Conference Proceedings Center for International Language Development of Unissula, 285-293. 